\title{
Right to Education and the Best Interest of a Child in the Constitutional Court Case Law
}

\author{
Olga Sovova ${ }^{1}$
}

\begin{abstract}
Inclusion is considered being a universal human right. Educational inclusion is a specific part of the mentioned matter. Usually, it targets children with disabilities to enable them to access mainstream education with their peers. Nevertheless, other issues may exclude children from their natural community. Parental separation, mutual disagreement, or other consequences of family breakdown form significant reasons for the necessity of specific legal measures in a child's best interest. The paper analyses the constitutional principles and requirements for ensuring the right to education based on the particular decisions of the Czech Constitutional Court. The paper highlights the case law on the child's best interest in connection with the right to education. The article also critically focuses on the balance between the right to peaceful family life, the right of parents to decide on a child's education, and the right of a child to selfdetermination. The paper concludes with de lege ferenda proposals based on Czech legal practice and case law.
\end{abstract}

\section{Keywords}

inclusion, education, best interest of a child, constitutional rights, case law

\section{Introduction}

Minors-children are in a specific position when dealing with their needs and rights. The right to education and the right for a peaceful family life protect parental authority and competency to and obligation to determine the content and scope of educational activities of their children.

There are situations where parents do not take the perspective of the best interest of their children. Some parents could not protect the best interest of the child because of their problems. Well-known examples are parents with unbalanced relationships after divorce, mental problems, addiction to drugs or alcohol, and parents with cognitive disabilities. The best interest of a child from the perspective of education and the public's interest could sometimes be quite different from the parents' interest.

Children in any time of need deserve increased attention from public authorities when including them in the education with their peers.

The inclusion of children with disabilities was a matter of interest and research for a longer time. The national literature emphasises equal opportunities as the aim and result of inclusion. The best interest of a child generally and especially in cases of family breakdown and parental disputes form the object of research interest. However, the challenge with children who are affected in their educational rights by the issues mentioned above of parental disagreement and become hostages of their parents is omitted so far. This paper examines the case-law of the Czech Constitutional Court (CC), highlighting the interconnection between the best interest of a child, the children's participation, self-determination and educational right and parents for the undisturbed family right, including child-rearing and care.

1 Associate Prof. Dr IUR. Olga Sovova, Ph. D., Center for Medical Law, Law Faculty, Charles University (Czech Republic). Police Academy of the Czech Republic in Prague. 
The Czech legal system belongs to the continental written legal system, with the German and Austrian historical background and similarities. The membership of the Czech Republic in the Council of Europe, legal binding of European Court of Human Rights (ECHR) decisions, and the European Union membership and the application primacy of the Community law approximate the Czech law and its interpretative rules to the precedent legal systems. The judgments of CC form sources of law just in case of publication as a law regulation in the Collection of Laws of the Czech Republic. Nevertheless, a CC judgment is always binding for general courts in a specific case. Moreover, judgments form a collection of model decisions, and the legal practice is getting closer to the principle of stare decisis. When the general court wants to change the established decision-making practice, the principle of distinguishing has become quite common. The private law regulation underlines these interpretative rules and the role of doctrine, too:

(1) Where a legal case cannot be decided on the basis of an express provision, it is assessed under the provisions concerning the legal case, which is, in terms of its content and purpose, the closest possible to the case under consideration.

(2) In the absence of such a provision, the legal case is to be assessed under the principles of fairness and the principles underlying this Act to arrive at a suitable arrangement of rights and duties regarding the. the practice of private life and taking into account the state of legal opinion and established decisionmaking practice. [1]

The importance of the judicial creation of the law is steadily growing. Due to globalisation, the number of cross-border families is increasing. It is necessary to use patterns and norms from foreign legal orders to solve national cases. The theory and legal practice are aware of it. [2] The educators and social workers should realise it as well.

The paper aims to cover the gap when presenting and analysing one specific judgment of the CC in educational cases.

The paper uses the methodology of desk research and analyses documents, as the case- law and literature. The author, being a family attorney-at-law, exploit her own practical experience. Based on this, the author interprets the findings and analysis according to standard methods of legal interpretation. The author also utilises the above-standard methods of interpretation, especially the comparative analysis with the ECHR decisions. Following an analysis of all this information, certain developmental tendencies shortly can be predicted, and the legal basis for protecting children's best interest in education could be set.

Under Article 3, para. 1 of the Convention on the Rights of the Child, the best interests of the child shall be a primary consideration in all actions concerning children, whether undertaken by public or private social welfare institutions, courts of law, administrative authorities or legislative bodies, the best interests of the child shall be a primary consideration. [3]

The Constitutional Court reiterates that the concept of the best interest of the child is flexible and adaptable. It should be adapted and defined individually given the specific situation of the child or children concerned, while attention should be paid to their circumstances, situation and needs.

\section{Case Presentation}

The mother of a minor girl, age 7, lodged the constitutional complaint on March 7 2018. The case file number is IV.US 827/18.[4]

According to the regional court's decision, on May 12 2015, the mother raises the child after the parents' separation. The father regularly meets the daughter. The father is not legally limited in contact with the minor neither deprived of parental rights. However, the parents have long-term disagreements, and the child becomes a hostage. Parental disputes about the minor's upbringing form the reason for the examined court case.

\section{Facts of the case}

The minor started her compulsory education at the private primary school, focusing on language education. Before, the minor had visited the kindergarten of the same provider. Both schools are bilingual, and the teaching goes on in the Czech and English languages. However, the father disagreed with the mother's decision about the private school. The father decided that the minor should attend the public school 
near his residence. Both parents started at the beginning of the year 2017 the proceedings of enrolling the minor on their respective chosen school. The private school enrolled the minor, and she started her primary education on September 1,2017. The father's school, due to parental disagreement, suspended the enrolment proceedings.

The father applied the family section of the district court, stating that according to the Czech Civil Code, section Family law, parents must arrange on essential matters of their minor children. Compulsory education and school choice are one of them. If not, the court must replace the consent of a mother. [5] The father underlined that the payment for private primary education exceeds the financial possibilities of both parents.

The district court dismissed the application, based on fact and legal evaluation, as provided below. The father appealed to the regional court, which ruled that the minor should change the school. So, the regional court replaced by its judgment the mother's agreement. The regional court decided on the same facts and findings as to the district court, but the legal evaluation differed.

There was no other legal remedy, except for the constitutional complaint, which the mother used.

\section{Courts Proceeding and the Content of the Contested Decisions}

The proceeding before the district court forms the core of the proceedings. According to the Czech Civil Procedural Code, Act. No. 99/1963 Coll., district courts are courts of the first instance. Their task is to gather and hear evidence. Parties' proposals do not bind the judge, as a separate law regulates the child protection proceeding-the Act No. 293/2013 Coll., on Special Court Proceedings. The investigation principle governs the proceeding, and the judge may seek evidence at her discretion. Adherence to this principle is crucial for the further development of the case. "In uncontested proceedings, the court plays the role of a kind of de facto police officer, much more has to search, investigate how things happened. These issues are typically the case in proceedings for the care of minors. " [6]

The district court appointed the municipality child protection service (CPS) as the conflict guardian in this case. CPS spoke with the minor. She stated that she liked the school the mother had chosen from the beginning. Her friends attended the same school. The mother provided an expert opinion, stating that the minor is very responsive and anxious and needs a smaller class team, which the private school offers. Based on these findings and evidence, the district court rejected the father's application.

The regional court being a court of appeal, overtook the evidence provided by the district court. The Civil Procedural Code calls courts of appeal upon assessing legal aspects of the case. They hear evidence only if it speeds up the proceedings and does not significantly affect the judgment. The regional court stated that the minor is in a difficult position because of her parents' disputes and inability to agree. She had been attending the school for six months already. However, the regional court ruled that the expert opinion did not state that she could not comply with changes. That is why the regional court ruled that the fatherś appeal is justified and granted consent with the school, which the father had chosen.

\section{Management and Outcome}

The mother lodged a constitutional complaint, as the legal regulation does not allow any extraordinary remedy. The constitutional complaint thus represents the only possibility of how to reverse the judgment of the court of appeal. Because of the urgent legal interest of the minor to stay at the current school, the complainant requested postponing the enforceability of the judgement. CC complied with the request.

\section{Summary of the complaint}

The mother (complainant) lodged a constitutional complaint, filed on time and complying with other formal requirements as prescribed by Act No. 182/1993 Coll. The complainant sought the annulment of the regional court's decision. The complainant found the decision of the court of appeal ill-founded. She stated that the decision was insensitive to the minor and infringed the minor's right to privacy according to Article 10 of the Charter of Fundamental Rights. Moreover, the complainant underlined that the father provided false information about his domicile. He would not be able to take care of the minor 
during her school attendance at the school he had chosen. She also pointed out that the regional court did not allow the parties to express their legal opinion and provide respective evidence. She considered the decision unlawful because of its surprise factor.

The father emphasised that the court of appeal observed all constitutional rights of parts and the minor. He pointed out that the change of the primary school could not be considered an infringement of constitutional rights to privacy protection and education.

The regional court stated that judges have complied with all procedural and material rights of the parties and enable them to provide evidence and express themselves to the court's legal opinion before the delivery of the judgment. An attorney represented the mother at the regional court.

The opinion of the CPS sees sub. 2.

\section{Scope of the Review of the Constitutional Court}

The CC reiterated his authority to review the decision of general courts: Under article. 83 of the Czech Republic Constitution, the Constitutional Court is thejudicial body responsible for protecting constitutionality . It has jurisdiction over constitutional complaints against final decisions or other encroachments by public authorities infringing constitutionally guaranteed fundamental rights and freedoms. However, the Constitutional Court is not part of the system of general courts, and as such, it is not competent to appellate review of their decisions. [7]

The CC reminded only the proposal in the case is binding. The CC is not obliged to accept the reasoning of the complaint. That is why the $\mathrm{CC}$ pointed out one fundamental issue, which the complainant had not appealed. Also, general courts had not considered it ex officio.

The CC found that only CPS asked the minor about her attitude as the primary infringement of the rights of the minor. The CC underlined that the interpretative rule, derived from the Convention on the Rights of Child, (Convention) Article 3, and repeatedly accentuated in many CC decisions "In all actions concerning children, whether undertaken by public or private social welfare institutions, courts of law, administrative authorities or legislative bodies, the child's best interests shall be a primary consideration." had been violated. [8]

The minor of age 7, who already attends the school, should express her opinion about her education, schoolmates and the teacher. The CC underlined that it is unlawful to interfere with her privacy and life without hearing her. The CC stressed that the minor is the victim of the parental disputes, and the regional court failed to protect her best interests.

The best interest of the minor consists of the right to express her view, according to Article 12 of the Convention. Further, it includes the right to a fair trial according to the Charter of Fundamental Rights and Freedoms.

The CC annulled the decision of the regional court. In new proceedings, the regional courts would be obliged to ascertain the child's opinion directly, not through other persons as before.

\section{Final Decision and the Outcome of the Case}

After the annulment of its judgment, the regional court reviewed the case. The assistant judge questioned the minor at school in the presence of CPS. The parents were not present. The court dismissed the father's request to record the interview. The court justified the dismissal with the concern for objectivity and contentment of the minor. If recording the interview, the minor might have felt controlled, and it would affect her opinion.

The minor said that she liked the school, she has already finished her first class. She stressed to be happy there because there are just 15 pupils in the class. She knows the school chosen by the father because she attends an athletic group there. She would not like to be enrolled at this school, as too many pupils are in one class-30. If she could choose, she would rather stay at her present school and attend the athletic group in the other one.

The court also heard evidence about the minor's school results because the father objected the bilingual education. He was afraid that the minor might not understand more complex subjects. The school reported that the minor has good results, and there are no signs that she might have issues with bilingual education. Concerning the necessity to pay the tuition fee, the mother provided the trust agreement. The grandparents obliged themselves to pay for the tuition and minor's further education. 
Based on the evidence and according to the legal opinion of the Constitutional Court, the district court changed its previous judgment. The court ruled that it is in the minor's best interest to remain at the existing school. So, the girl wishes, as she has there her friends, and she likes the teachers. The minor also complies well with bilingual teaching. The court concluded that it is in the minor's favour to develop herself in the school, where she feels good. As the trust beneficiary, the minor will have enough financial resources to finish the compulsory education there. [9]

\section{Discussion}

The authority of the Constitutional Court serves to review decisions against which a complaint is directed exclusively in terms of compliance with constitutional law principles.

CC constantly develops children's rights in its case law. CC has long emphasised the need to consider the child's best interests in all actions concerning the child, including judicial decision-making. The Constitutional Court reiterates that the concept of the best interest of the child is flexible and adaptable. It should be adapted and defined individually because of the specific situation of the child or children concerned, while attention should be paid to their circumstances, situation and needs.

Considering the meaning of the mentioned case - law, the author examines inclusion as the right of a child to participate actively in all major decisions concerning her daily life and future. The right to privacy, self-determination and education belong to a person's fundamental rights and children.

The examined decision stands in the middle of essential CC decisions concerning children's rights for primary education. Other model decisions include the judgment about violating children's rights by the additional postponement of compulsory school attendance due to parental conflict. [10] The recent decision about the infringement of the obligation to adequately substantiate the court decision and the child's best interest highlights the surprising verdict of the court of appeal that changed the child's residence and education. [11]

In all cases, the parents' conflict caused the litigation: the parents could not agree, and they used the child as a tool ad hostage agist each other. The general courts did not consider the child's best interest, concentrating just on legal issues among parents. The Constitutional Court had to intervene because children were just an object of the decisive power of courts. As the CC reiterated in many reasonings of its decisions, the child must be a subject of the proceedings.

According to the authoritative interpretation of the Committee on the Rights of the Child, "whenever a decision is to be made that will affect a specific child, ... the decision-making process must include an evaluation of the possible impact (positive or negative) of the decision on the child or children concerned. ... The justification of a decision must show that the [best interest of the child] has been explicitly considered [General comment No. 14 on the right of the child to have his or her best interests taken as primary consideration), dated May 29 2013, CRC/C/GC/14, § 6, similarly § 29. [3. Sub-26]

\section{Conclusion and implications}

The Czech Republic is always very attentive to children in need. The legal regulation is lagging behind the current problems, but the need for changes follows from the analysis of court decisions.

Procedures that are at the judge's discretion should be mandatory in the best interest of a child. The judge can order one visit at the mediator. The author would suggest that in cases of parental disputes about the crucial decisions concerning the future of a minor, mediation should be obligatory.

The judge should always hear the minor if she has been already enrolled in school. The state should create such material conditions that enable to hear the child in friendly surroundings, not in the courtroom. Many police stations nowadays have a special playroom to interrogate a child in need. The same could be arranged at selected district courts.

If the parents would not be able to settle the dispute, even with the help of the court and mediator, they should pay a court fee, in the amount which would have an educational purpose in such a case.

Child protection services usually do their best in the interest of children in court proceedings. However, the procedure requires a profound knowledge of procedural and positive law, including case law and doctrine. The judge can always appoint the attorney-at-law to represent the minor. The author would suggest that in all cases concerning parental disagreements, an attorney for the child should be 
appointed on parents' costs, provided the child is not mature enough to choose her legal representativesee above in discussion.

The welfare state replaced families in many fields. Education in kindergartens and schools prevails in children's everyday lives. Schools also provide after-school programmes. Childhood is much more institutionalised. Teachers, social workers and judicial bodies need to emphasise the humanity of all members of society and avoid social stigmatising of vulnerable groups. [12]

Participatory rights form an integral part of the European and Czech legal order. Most courts and child protection services include them in their decisive daily practice without any issues.

However, some parents still do not unsderstand the meaning and limits of the participatory rights of their children. Authoritarian education often violates the rights of the child. Excessive freedom and exaggeration of self-determination can lead to indiscipline and incompetence to join the collective.

The expert intervention and inclusion of a child are necessary in both cases. In the post-modern digital, globalised society, children have enough information and are much more capable of protecting their rights. Social media and the disclosure and discussion about severe cases and court decisions in children's matters help state authorities, schools, families, and children understand the participatory right throughout its scope.

\section{References}

[1] Section 10, Act No. 89/2012 Coll., the Civil Code [Online]. Retrieved August 20 2021, from: http:// obcanskyzakonik.justice.cz/images/pdf/Civil-Code.pdf.

[2] Bobek, M.: Comparative Reasoning in European Supreme Courts. (2013). Oxford University Press, New York. p. 9

[3] Convention on the Rights of the Child [Online]. Retrieved August 20, 2021, from: https://www. ohchr.org/en/professionalinterest/pages/crc.aspx

[4] Decision IV. US 827/18, dated April 10 2018[Online]. Retrieved August 20, 2021, from https://nalus. usoud.cz/Search/ResultDetail.aspx?id=101765\&pos=1\&cnt=2\&typ=result.

[5] Section 692. Civil Code, Act. No 89/2021 Coll. [Online]. Retrieved August 20, 2021, from http:// obcanskyzakonik.justice.cz/images/pdf/Civil-Code.pdf

[6] Jirsa, J. Zákon o zvláštních řízeních soudních a procesní úvahy de lege ferenda. Online]. Retrieved August, 20, 2021, from https://www.pravniprostor.cz/clanky/procesni-pravo/zakon-0-zvlastnichrizenich-soudnich-a-procesni-uvahy-de-lege-ferenda.

[7] For details, see the Decision I. ÚS 2482/13, dated May 26 2013[Online]. Retrieved August 20, 2021, from: https://www.usoud.cz/en/decisions/2014-05-26-i-us-2482-13-joint-custody.

[8] Decision I. US 3226/16, dated June 29 2017[Online]. Retrieved August 20, 2021, from: https://www. usoud.cz/fileadmin/user_upload/ustavni_soud_www/Decisions/pdf/1-3226-16.pd.

[9] The case file number is 32 Co 436/2017. dated July 30, 2018 [Online]. Retrieved August 20, 2021, from: https://www.justice.cz/documents/1729/1858556/Si+32-2019+

[10] Decision IV. ÚS 3749/17, dated January 92018 [Online]. Retrieved August 20, 2021, from: https:// nalus.usoud.cz/Search/ResultDetail.aspx?id=100417\&pos=1\&cnt=2\&typ=result

[11] Decision II.ÚS 1338/20, dated March 32021 [Online]. Retrieved August 20, 2021, from: https:// nalus.usoud.cz/Search/ResultDetail.aspx?id=115382\&pos=1\&cnt=3\&typ=result

[12] Gullestad, M.: Plausible Prejudice: Everyday Experiences and Social Images of Nation, Culture and Race. (2006). Universitetsfolaget, Oslo, UK edition. pp.143 a 144 